\title{
Fire-resistance, Physical, and Mechanical Characterization of Binderless Rice Straw Particleboards
}

\author{
Cristina C. Ferrandez-Garcia, Teresa Garcia-Ortuño, Maria T. Ferrandez-Garcia, \\ Manuel Ferrandez-Villena, and Clara. E. Ferrandez-Garcia*
}

\begin{abstract}
Binderless rice straw particleboards were successfully manufactured by hot pressing at low temperatures $\left(110^{\circ} \mathrm{C}\right)$ while under pressure $(2.6$ $\mathrm{MPa})$ using a three-step process. Two particle sizes were used: 0.25 to $1.00 \mathrm{~mm}$ and 0.00 to $0.25 \mathrm{~mm}$. Three pressing times $(15 \mathrm{~min}, 30 \mathrm{~min}$, and $60 \mathrm{~min}$ ) were studied. Eighteen types of boards were made. The physical and mechanical properties were assessed in accordance with the European Standards for wood-based particleboards, namely density, thickness swelling, water absorption, thermal conductivity, modulus of rupture, modulus of elasticity, internal bonding strength, and reaction to fire. Two panels exceeded the requirements for general uses. The panels had a low thermal conductivity $(0.076 \mathrm{~W} / \mathrm{mK}$ to $0.091 \mathrm{~W} / \mathrm{mK})$. The panels were classified in the same class as the fire retardants (class Bd0, according to EN ISO 11925-2:2002)
\end{abstract}

Keywords: Oryza sativa; Reaction to fire; Flammability; Bio-based panels; Self-bonded

Contact information: Department of Engineering, Polytechnic School of Orihuela, Universidad Miguel Hernández de Elche, Elche, Spain; *Corresponding author: cferrandez@umh.es

\section{INTRODUCTION}

Rice is one of the most important crops in the world. According to FAO, rice production in 2015 reached 750 million tons. As for every ton of grain harvested there is one ton of straw left, after the harvest there were 750 million tons of rice straw globally on the fields. Rice growers usually deal with unwanted straw by burning it on site, resulting in a significant emission of $\mathrm{CO}_{2}$ and contributing to air pollution. The increasing awareness of climate change, deforestation, and environmental pollution, has driven the research of agricultural residues to produce building materials, including particleboards (Li et al. 2010). Rice straw is a renewable lignocellulosic waste, and several researchers have studied the feasibility of turning these residues into useful products, such as particleboard, fiberboard, and filler, for thermoplastic composites (Halvarsson et al. 2010; Li et al. 2010; Zang and $\mathrm{Hu} 2014$ ).

Traditionally, straw has been used in building materials as an insulator due to its multiple advantages over other materials: availability, renewability, and low thermal conductivity, while also being lightweight. It was used under wood floors, under roofs, and to fill walls throughout Europe for decades.

Rice straw is composed of $12.3 \%$ lignin, $36.5 \%$ cellulose, $27.7 \%$ hemicellulose, $6.1 \%$ water-soluble extractives, $3.8 \%$ wax, and $13.3 \%$ ash (Ghaffar and Fan 2014), while softwoods have 25 to $28 \%$ lignin, 42 to $46 \%$ cellulose, 7 to $12 \%$ hemicellulose, 1 to $8 \%$ extractives and 0.3 to $1.3 \%$ of ash (Sjöström 1993). In comparison with wood, straw has several drawbacks when used as a substitute in particleboard manufacturing. Straw has 
less lignin and cellulose, and a higher hemicellulose and ash content than wood, resulting in poor mechanical properties and a greater absorption of water when particleboards are manufactured following the parameters of the wood particleboard industry (Rials and Wolcott 1997). To improve their properties, straw particles need to be pretreated and subjected to more extreme pressing conditions (Pintiaux et al. 2015). In the first attempts of using straw for board-making, it was reported that the presence of a waxy outer layer had a negative impact due to its low wettability, which made its union with thermosetting resins incompatible. The research showed that the incompatible layer needed to be removed (Sauter 1996; Han et al. 2001; Boquillon et al. 2004; Hervillard et al. 2007). In contrast, the increasing concern about the potential toxicity of synthetic binders has led researchers to focus their studies on manufacturing a "binderless" layer. Several reviews on this matter have been recently conducted (Pintiaux et al. 2015; Zhang et al. 2015). This research highlights the severity of the parameters that were used to achieve good physical and mechanical performance: a steam injection pretreatment, very high pressing temperatures, and very high pressure. In a previous study, Ferrandez-Garcia et al. (2012) developed a method to manufacture particleboards using low temperatures during hot pressing along with three pressing steps. The raw materials used were particles of the giant reed (Arundo donax L.), which were bonded with non-modified starches. The method seemed to be promising for other agro-lignocellulosic materials. According to Park et al. (2009) the stem of rice plants contain starch that accounts for sometimes > $20 \%$ of the dry weight. Consequently, self-bonded particleboards of rice straw could be manufactured by hot pressing with the three-step method, taking advantage of the fact that rice straw contains starch.

An important issue surrounding bio-based building materials is the lack of knowledge concerning their reaction to fire. Renewable building materials have the potential to partly replace commonly used materials such as cement, yet important requirements need to be fulfilled. Fire safety must be addressed, according to the EU Construction Product Regulation No. 305/2011, CPR. A few studies were conducted to investigate the fire reaction of boards made of or containing agricultural residues, such as rice husk (Kim 2009) and kenaf (Lee et al. 2014). However, there is no information available in the literature of the reaction between fire and binderless rice-straw particleboards.

This research aims to manufacture binderless particleboards of rice straw using a low pressing temperature and pressure to study the boards' physical-mechanical properties, and their reaction to fire. The influence of particle size and pressing time were variables studied to select the best performing boards.

\section{EXPERIMENTAL}

\section{Materials}

The rice straw was supplied by IVIA (Valencian Institute of Agricultural Research, Valencia, Spain) from the Albufera nature reserve (Valencia). The straw was chipped in a laboratory-scale ring-knife chipper (Manufacturer, Elche, Spain). The particles were then classified, using a horizontal screen shaker. Two particle sizes were used in this study: the particles that passed the sieve of $1 \mathrm{~mm}$ but were retained on the sieve of $0.25 \mathrm{~mm}$, and the particles that passed through the $0.25 \mathrm{~mm}$ sieve. No binder was employed in the manufacturing of the particleboards. 


\section{Methods}

Manufacture of rice-straw binderless particleboards

The method used to manufacture the particleboards was adapted from FerrandezGarcia et al. (2012), with the particularity that no binder was used. Eighteen types of panel were made, and each panel was prepared with $2000 \mathrm{~g}$ of particles and $200 \mathrm{~g}$ of distilled water. Five repetitions were made for every panel type.

Boards measuring $600 \mathrm{~mm} \times 400 \mathrm{~mm} \times 9 \mathrm{~mm}$ were manually pre-formed in a mold and then pressed in a hot-press under $2.6 \mathrm{~N} / \mathrm{mm}^{2}$ at $110{ }^{\circ} \mathrm{C}$ for $15 \mathrm{~min}, 30 \mathrm{~min}$, and/or $60 \mathrm{~min}$. After pressing, the boards remained in the mold without pressure to cool for $1 \mathrm{~h}$ under ambient conditions. After that, two thirds of the particleboards were brushed with distilled water at a rate of $120 \mathrm{~g} / \mathrm{m}^{2}$ on the upper surface and then they were hot-pressed again under the same pressing conditions. Subsequently, one third of the panels were subjected to a third pressing cycle. The pressing temperature was kept low $\left(110{ }^{\circ} \mathrm{C}\right)$ to avoid surface burning given that some pressing times were long. The experimental design is shown in Table 1.

Table 1. Manufacturing Conditions of the Straw-particleboards

\begin{tabular}{|c|c|c|c|c|c|}
\hline Particleboard Type & $\begin{array}{l}\text { Particle Size } \\
\qquad(\mathrm{mm})\end{array}$ & $\begin{array}{l}\text { Pressing } \\
\text { Pressure } \\
\left(\mathrm{N} / \mathrm{mm}^{2}\right)\end{array}$ & \begin{tabular}{|c|} 
Pressing \\
Temperature \\
$\left({ }^{\circ} \mathrm{C}\right)$
\end{tabular} & $\begin{array}{l}\text { Pressing Time per Cycle } \\
\text { (min) }\end{array}$ & Cycles \\
\hline 1 & $<0.25$ & 2.6 & 110 & 15 & 1 \\
\hline 2 & $<0.25$ & 2.6 & 110 & 15 & 2 \\
\hline 3 & $<0.25$ & 2.6 & 110 & 15 & 3 \\
\hline 4 & $<0.25$ & 2.6 & 110 & 30 & 1 \\
\hline 5 & $<0.25$ & 2.6 & 110 & 30 & 2 \\
\hline 6 & $<0.25$ & 2.6 & 110 & 30 & 3 \\
\hline 7 & $<0.25$ & 2.6 & 110 & 60 & 1 \\
\hline 8 & $<0.25$ & 2.6 & 110 & 60 & 2 \\
\hline 9 & $<0.25$ & 2.6 & 110 & 60 & 3 \\
\hline 10 & 0.25 to 1 & 2.6 & 110 & 15 & 1 \\
\hline 11 & 0.25 to 1 & 2.6 & 110 & 15 & 2 \\
\hline 12 & 0.25 to 1 & 2.6 & 110 & 15 & 3 \\
\hline 13 & 0.25 to 1 & 2.6 & 110 & 30 & 1 \\
\hline 14 & 0.25 to 1 & 2.6 & 110 & 30 & 2 \\
\hline 15 & 0.25 to 1 & 2.6 & 110 & 30 & 3 \\
\hline 16 & 0.25 to 1 & 2.6 & 110 & 60 & 1 \\
\hline 17 & 0.25 to 1 & 2.6 & 110 & 60 & 2 \\
\hline 18 & 0.25 to 1 & 2.6 & 110 & 60 & 3 \\
\hline
\end{tabular}

\section{Measurement of physical and mechanical properties}

Some physical and mechanical properties were determined in accordance with the appropriate European Standards: density (EN 323, 1993), water absorption (WA), and thickness swelling (TS) after $2 \mathrm{~h}$ and $24 \mathrm{~h}$ of immersion (EN 317, 1993), modulus of rupture (MOR) and modulus of elasticity (MOE) (EN 310, 1993), and internal bonding (IB) (EN 319, 1993). In addition, the thermal conductivity (EN 12667, 2001) and the reaction to fire using a single-flame source (ISO 11925-2, 2010) were measured. Each panel was cut to get six density samples $(50 \mathrm{~mm} \times 50 \mathrm{~mm})$, three WA/TS samples $(70$ $\mathrm{mm}$ x $70 \mathrm{~mm}$ ), six MOR/MOE samples (different lengths, depending on the thickness, $\mathrm{x}$ 
$50 \mathrm{~mm}$ width), and three IB samples $(50 \mathrm{~mm} \times 50 \mathrm{~mm})$. The tests for the mechanical properties, WA, TS, and density were conducted on a laboratory universal testing machine (Model IB600, Imal S.r.l, Modena, Italy). The tests for the thermal conductivity were performed on a heat flow meter instrument (model HFM 436/3/0, NETZSCH Gerätebau GmbH, Selb, Germany), using one sample of each board (300 mm x $300 \mathrm{~mm}$ ). Reaction to fire tests were performed on a flammability meter (CEAST model 1653, Torino, Italy) following the EN ISO 11925-2 (2002). Particleboards were then classified according to EN-13501-1: 2007+A1 (2009). Three boards with different particle sizes were used to get a sample measuring $90 \mathrm{~mm}$ x $250 \mathrm{~mm}$ to perform the reaction to fire test. The panels selected had achieved the best mechanical behavior. The boards were conditioned prior to the test to a constant mass at a temperature of $23{ }^{\circ} \mathrm{C} \pm 2{ }^{\circ} \mathrm{C}$ and a relative humidity of $60 \% \pm 5 \% \mathrm{RH}$. The samples were vertically fixed in the frame, and a flame was applied for $30 \mathrm{~s}$ with an inclination of $45^{\circ}$ impinged $40 \mathrm{~mm}$ above the bottom edge (surface exposure). The occurrence of burning particles is observed with filter paper placed below the specimen. The total test duration is $60 \mathrm{~s}$ from the time at which the flame is first applied. For each test sample it is recorded whether an ignition occurs (flaming for a period greater than $3 \mathrm{~s}$ ), whether ignition of the filter paper occurs, and whether smoke is produced.

The data for each test were analysed statistically. Analysis of variance (ANOVA) and t-tests calculations were used to test $(\alpha=0.05)$ for significant differences between factors and levels using the IBM SPSS statistic base (IBM, spss 20, NY, USA). A comparison of the means was performed when the ANOVA indicated a significant difference, employing Duncan's test.

\section{RESULTS AND DISCUSSION}

\section{Physical Properties}

The results of density, thickness swelling, water absorption, and thermal conductivity of the produced particleboards are shown in Table 2. Rice straw binderless panels with densities in the $980 \mathrm{~kg} / \mathrm{m}^{3}$ to $1148 \mathrm{~kg} / \mathrm{m}^{3}$ range were successfully manufactured. This property did not depend on the particle size nor the pressing time.

\section{Thickness swelling and water absorption}

Particleboards should have a maximum thickness swelling value of $16 \%$ for $24 \mathrm{~h}$ immersion for load bearing (P4 grade according to EN 312 (2010)), and there is no TS requirement in the standards for general uses and furniture manufacturing in dry ambient conditions (P1 and P2 grades, respectively).

The average thickness swelling of the specimens after $2 \mathrm{~h}$ of immersion ranged from $11.3 \%$ to $59.7 \%$. After $24 \mathrm{~h}$ of immersion, the results were between $23.2 \%$ and $60.7 \%$. This property depended on the particle size and the number of pressing cycles; thus the boards made with the smaller particles swelled less in thickness than the rest and regarding the number of pressing cycles, in all cases the boards made with only one cycle were the ones that had a lowest TS. This phenomenon did not occur with the boards made with the coarser particle size. The TS and WA values were in accordance with other binderless particleboards (Lindström and Westman 1980; Bouajila et al. 2005).

Ferrandez-Garcia et al. (2017). "Binderless RS boards," BioResources 12(4), 8539-8549. 8542 
Table 2. Average Results of Physical and Thermal Properties

\begin{tabular}{|c|c|c|c|c|c|c|}
\hline $\begin{array}{l}\text { Panel } \\
\text { Type }\end{array}$ & $\begin{array}{r}\text { Density } \\
\left(\mathrm{kg} / \mathrm{m}^{3}\right)\end{array}$ & $\begin{array}{c}\text { TS } 2 \text { h } \\
(\%)\end{array}$ & $\begin{array}{c}\text { TS } 24 \mathrm{~h} \\
(\%)\end{array}$ & $\begin{array}{c}\text { WA } 2 \text { h } \\
(\%)\end{array}$ & $\begin{array}{l}\text { WA } 24 \mathrm{~h} \\
(\%)\end{array}$ & $\begin{array}{l}\text { Conductivity } \\
(\mathrm{W} / \mathrm{mK})\end{array}$ \\
\hline 1 & $1046.46(19.30)$ & $14.27(0.64)$ & $33.14(1.14)^{c}$ & $34.16(0.43)$ & $48.79(9.06)^{\mathrm{a}}$ & $0.078(0.006)^{*}$ \\
\hline 2 & $1128.77(84.76)$ & $13.37(1.18)$ & $36.36(1.76)^{\mathrm{cd}}$ & 35.40 (4.39) & $54.42(1.79)^{\mathrm{a}}$ & $0.088(0.009)^{*}$ \\
\hline 3 & $1135.67(1.80)$ & $48.06(1.76)$ & $60.69(0,34)^{i}$ & 75.93 (4.13) & $87.13(2.28)^{d}$ & $0.084(0.000)^{*}$ \\
\hline 4 & $1086.27(9.89)$ & $13.69(1.58)$ & $30.52(1.01)^{b}$ & 38.44 (2.17) & $48.02(3.27)^{\mathrm{a}}$ & $0.080(0.011)^{*}$ \\
\hline 5 & $1049.01(6.17)$ & $24.78(3.73)$ & $41.84(1.71)^{\mathrm{e}}$ & 48.68 (2.82) & $67.27(2.65)^{\mathrm{b}}$ & $0.082(0.004)^{*}$ \\
\hline 6 & 1147.86 (13.39) & $47.88(1.63)$ & $53.73(1,75)^{g h}$ & $70,62(0.71)$ & $84.26(0.85)^{d}$ & $0.076(0.001)^{*}$ \\
\hline 7 & $1088.63(4.09)$ & 11. & $23.15(0.88)^{a}$ & 33.5 & $45.74(0.05)^{\mathrm{a}}$ & $0.091(0.001)^{*}$ \\
\hline 8 & $1118.35(28.46)$ & $12.73(2.35)$ & $26.14(0.46)^{\mathrm{ab}}$ & 29.65 (3.90) & $44.54(1.30)^{\mathrm{a}}$ & $0.082(0.005)^{*}$ \\
\hline 9 & 1101.54 (18.02) & 34.0 & $46.58(2.12)^{\mathrm{ef}}$ & 58.1 & $73.59(0.25)^{b c}$ & $0.076(0.002)^{*}$ \\
\hline 10 & $997.46(13.21)$ & $56.50(2.13)$ & $60.78(0.51)^{i}$ & $107.40(1.5)$ & $133.12(1.35)^{g}$ & $0.077(0.004)^{\star}$ \\
\hline 11 & 1015.86 & 42.5 & 50.08 & 86.93 & $101.86(4.05)^{\mathrm{e}}$ & $0.090(0.002)^{*}$ \\
\hline 12 & $1102.97(2.82)$ & $59.74(4.11)$ & $64.25(2.16)^{i}$ & 92.19 (2.39) & $102.70(1.99)^{\mathrm{e}}$ & $0.088(0.015)^{*}$ \\
\hline 13 & 979.85 (25.01) & $43.37(4.93)$ & $59.01(0.90)^{\mathrm{h}}$ & 78.29 (1.93) & $91.58(11.82)^{\mathrm{de}}$ & $0.083(0.010)^{*}$ \\
\hline 14 & $1099.91(97.25)$ & $38,8(10.97)$ & $54.04(3.18)^{g h}$ & $59.24(9.46)$ & $72.53(12.32)^{b}$ & $0.087(0.006)^{*}$ \\
\hline 15 & $1074.82(84.54)$ & $44.6(11.15)$ & $55.90(1.85)^{\mathrm{h}}$ & 70.68 (16.92) & $82.69(8.59)^{\mathrm{c}}$ & $0.081(0.003)^{*}$ \\
\hline 16 & $1007.38(83.40)$ & $46.57(5.51)$ & $53.70(5.92)^{g h}$ & $96.25(0.50)$ & $114.49(2.69)^{f}$ & $0.084(0.010)^{*}$ \\
\hline 17 & $1081.38(31.82)$ & $45.49(5.01)$ & $54.51(3.48)^{g h}$ & $64.12(5.54)$ & $81.51(4.17)^{g h}$ & $0.080(0.004)^{*}$ \\
\hline 18 & $1122.68(38.34)$ & $50.62(5.70)$ & $55.70(4.79)^{g h}$ & 75.11 (2.06) & $91.52(7.35)^{g h}$ & $0.078(0.005)^{\star}$ \\
\hline
\end{tabular}

Values in parenthesis are standard deviation; values with the same letter in the same column are not significantly different based on Duncan's multiple-range test at the 0.05 significance level; TS: Thickness swelling after $2 \mathrm{~h}$ and $24 \mathrm{~h}$ in water; WA: water absorption after $2 \mathrm{~h}$ and $24 \mathrm{~h}$ water immersion

One of the major problems of the self-bonded panels was their low water resistance. This property is usually expressed as the combination of TS and WA. Pintiaux et al. (2015) reported in their research that binderless boards had difficulties achieving water resistances that satisfied general standards. It is well known that non-woody materials, such as straw, have more hemicellulose than woody materials, and are therefore more hydrophilic. Halvarsson et al. (2010) reported a value of TS and WA of $75 \%$ and $90 \%$, respectively, with selected boards made from pretreated wheat straw.

The results of TS and WA of some of the experimental panels of the present study were good, considering that no waxes were added. The boards made with the smaller particle size absorbed less water than the boards with bigger particles. This could have been caused by the major content of silica refined from the cuticle when chipping the stems. Generally, the silica particles passed through the sieve with openings of $0.25 \mathrm{~mm}$. Kurokochi and Sato (2015) made binderless rice straw particleboards by hot pressing at $200{ }^{\circ} \mathrm{C}$ with $5 \mathrm{MPa}$ for $10 \mathrm{~min}$. They obtained boards with similar TS and WA values and concluded that the wax-like substances of the epidermis of the rice straw contributed to the water resistance property of the board. 


\section{Thermal conductivity}

Table 2 shows the results of the thermal conductivity tests. The thermal conductivity value of the experimental panels was low; it ranged from $0.076 \mathrm{~W} / \mathrm{mK}$ to $0.091 \mathrm{~W} / \mathrm{mK}$. These values were not influenced by the particle size nor the pressing time. The results were lower than those of the natural wood and woody particleboards. MacLean (1941) reported values of thermal conductivity of wood in the range of 0.70 to $1.19 \mathrm{~W} / \mathrm{mK}$. As for wood-based particleboards, their thermal conductivity lays between 0.07 and $0.18 \mathrm{~W} / \mathrm{m} \mathrm{K}$ according to EN 13986 (2015). Hence, the boards produced with rice straw particles can be considered good thermal insulating panels. However, to be used as an insulating material, the density of the particleboards must be reduced.

\section{Mechanical Properties}

Based on EN 312 (2010), the minimum requirements for general uses in dry ambient conditions are a MOR value of $11.5 \mathrm{~N} / \mathrm{mm}^{2}$ and an IB value of $0.24 \mathrm{~N} / \mathrm{mm}^{2}$ (P1 grade). A MOR value of $13 \mathrm{~N} / \mathrm{mm}^{2}$, a MOE value of $1600 \mathrm{~N} / \mathrm{mm}^{2}$, and an IB value of $0.35 \mathrm{~N} / \mathrm{mm}^{2}$ are the minimum requirements for furniture manufacturing ( $\mathrm{P} 2$ grade). For load bearing (P4 grade), the values of MOR, MOE, and IB are $15 \mathrm{~N} / \mathrm{mm}^{2}, 2300 \mathrm{~N} / \mathrm{mm}^{2}$, and $0.35 \mathrm{~N} / \mathrm{mm}^{2}$, respectively.

Table 3. Mean Values of Mechanical Properties of Rice Straw Particleboards

\begin{tabular}{|c|c|c|c|}
\hline Type & MOR $\left(\mathrm{N} / \mathrm{mm}^{2}\right)$ & MOE $\left(\mathrm{N} / \mathrm{mm}^{2}\right)$ & IB $\left(\mathrm{N} / \mathrm{mm}^{2}\right)$ \\
\hline 1 & $10.67(0.13)^{\mathrm{e}}$ & $1337.53(17.36)^{\mathrm{d}}$ & $0.04(0.00)^{\mathrm{cd}}$ \\
\hline 2 & $12.14(0.41)^{\mathrm{f}}$ & $1542.13(14.64)^{\mathrm{fg}}$ & $0.09(0.01)^{\mathrm{e}}$ \\
\hline 3 & $12.52(0.13)^{\mathrm{fg}}$ & $1848.05(50.09)^{\mathrm{h}}$ & $0.08(0.01)^{\mathrm{e}}$ \\
\hline 4 & $11.94(0.20)^{\mathrm{f}}$ & $1511.18(56.79)^{\mathrm{f}}$ & $0.10(0.00)^{\mathrm{e}}$ \\
\hline 5 & $11.32(0.67)^{\mathrm{e}}$ & $1429.26(36.24)^{\mathrm{e}}$ & $0.16(0.01)^{\mathrm{g}}$ \\
\hline 6 & $15.09(0.28)^{\mathrm{h}}$ & $2696.85(95.11)^{\mathrm{i}}$ & $0.18(0.01)^{\mathrm{g}}$ \\
\hline 7 & $13.08(0.18)^{\mathrm{g}}$ & $1458.38(73.99)^{\mathrm{e}}$ & $0.15(0.01)^{\mathrm{f}}$ \\
\hline 8 & $17.54(0.54)^{\mathrm{i}}$ & $1885.60(25.43)^{\mathrm{h}}$ & $0.28(0.02)^{\mathrm{h}}$ \\
\hline 9 & $18.02(0.42)^{\mathrm{i}}$ & $2587.44(37.72)^{\mathrm{i}}$ & $0.30(0.01)^{\mathrm{i}}$ \\
\hline 10 & $4.84(0.68)^{\mathrm{a}}$ & $587,84(99.46)^{\mathrm{a}}$ & $0.01(0.00)^{\mathrm{a}}$ \\
\hline 11 & $4.79(0.49)^{\mathrm{a}}$ & $542.77(56.82)^{\mathrm{a}}$ & $0.02(0.01)^{\mathrm{a}}$ \\
\hline 12 & $6.34(0.37)^{\mathrm{b}}$ & $841,29(61.13)^{\mathrm{b}}$ & $0.04(0.01)^{\mathrm{bc}}$ \\
\hline 13 & $6.23(0.01)^{\mathrm{b}}$ & $913,34(96.12)^{\mathrm{bc}}$ & $0.03(0.00)^{\mathrm{b}}$ \\
\hline 14 & $8.27(0.72)^{\mathrm{c}}$ & $1005.00(133.19)^{\mathrm{c}}$ & $0.02(0.01)^{\mathrm{a}}$ \\
\hline 15 & $8.52(0.22)^{\mathrm{c}}$ & $1469.02(149.64)^{\mathrm{e}}$ & $0.03(0.01)^{\mathrm{a}}$ \\
\hline 16 & $9.49(0.33)^{\mathrm{d}}$ & $1221.77(69.10)^{\mathrm{d}}$ & $0.04(0,01)^{\mathrm{bc}}$ \\
\hline 17 & $8.48(0.24)^{\mathrm{c}}$ & $1463.34(59.25)^{\mathrm{e}}$ & $0.04(0.01)^{\mathrm{bc}}$ \\
\hline 18 & $8.20(0.74)^{\mathrm{c}}$ & $1501.73(100.32)^{\mathrm{fg}}$ & $0.05(0.01)^{\mathrm{cd}}$ \\
\hline
\end{tabular}

Values in parenthesis are standard deviations; values with the same letter in the same column are not significantly different based on Duncan's multiple-range test at the 0.05 significance level 
Table 3 shows the results of the mechanical tests. The MOR values ranged from $4.79 \mathrm{~N} / \mathrm{mm}^{2}$ to $18.02 \mathrm{~N} / \mathrm{mm}^{2}$. The MOE values were between $542 \mathrm{~N} / \mathrm{mm}^{2}$ and 2696 $\mathrm{N} / \mathrm{mm}^{2}$. The IB test results ranged from $0.02 \mathrm{~N} / \mathrm{mm}^{2}$ to $0.30 \mathrm{~N} / \mathrm{mm}^{2}$. The mechanical properties were highly dependent upon the particle size and the number of pressing cycles. The best results were achieved by the boards made with the smaller particle size for the three properties. The mechanical values increased when the pressing times and cycles increased. Boards 8 and 9 exhibited better mechanical behaviour. These boards were made with a small particle size and $60 \mathrm{~min}$ of pressing, after the second and third pressing cycles, respectively. Figure 1 clearly shows the influence of the particle size and the pressing time on the experimental panels.

Boards 8 and 9 showed a value of MOR and MOE that exceeded the standard for load bearing ( $\mathrm{P} 4$ grade), but failed to comply with the IB minimum requirement of 0.35 $\mathrm{N} / \mathrm{mm}^{2}$. Thus, these panels could only be classified as grade P1, for general uses. Although the density of the panels was high, the internal bonding strength was poor. Presumably, the temperature and pressure of the hot pressing step was not enough for the starch to exhibit its adhesive capability. Ferrandez-Garcia et al. (2012) used the same conditions to bond particles of giant reed with starch, and obtained slightly better IB values. However, with higher temperature and pressure, Kurokochi and Sato (2015) reported lower values of IB (ranging from $0.01 \mathrm{~N} / \mathrm{mm}^{2}$ to $0.17 \mathrm{~N} / \mathrm{mm}^{2}$ ) for binderless rice straw panels made by hot pressing with $1 \mathrm{~mm}$ particles.

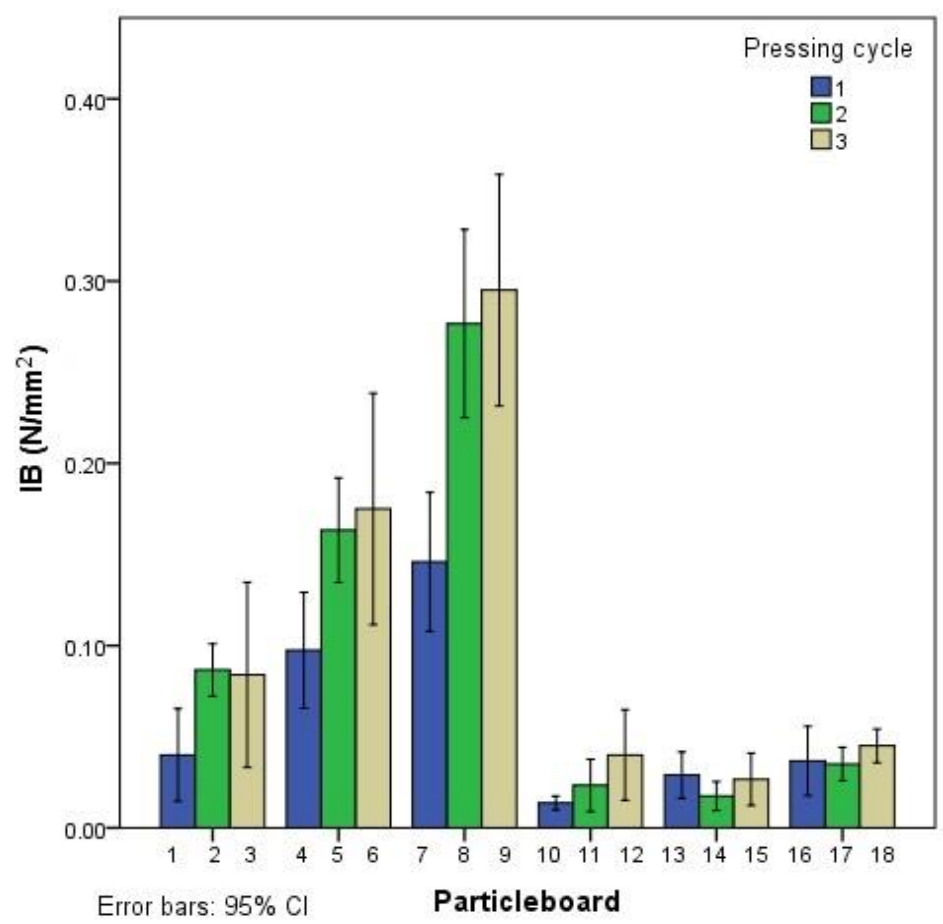

Fig. 1. IB values of binderless particleboards

\section{Reaction to Fire Test Results}

The panels selected for the test had achieved the best mechanical behaviour (boards 9 and 18). Figure 2 shows the samples vertically fixed in the frame after applying the flame. In Fig. 3 the effects of the fire can be seen in some of the samples. 

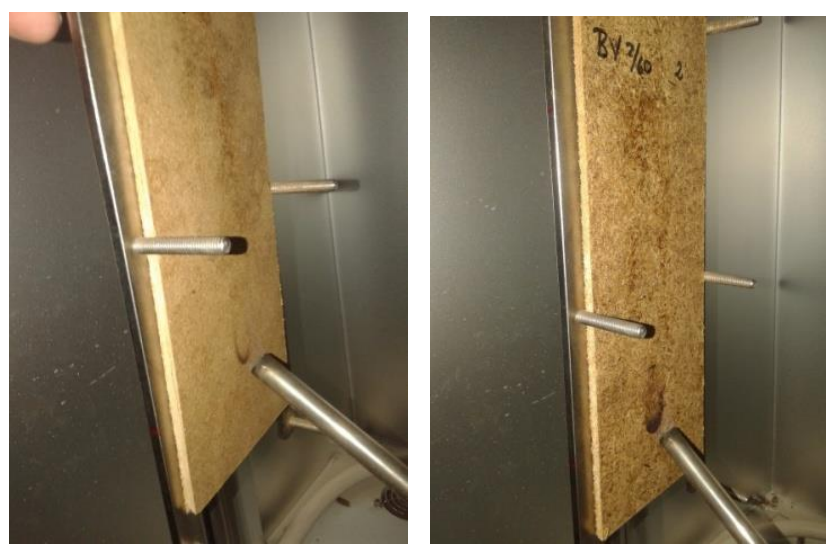

Fig. 2. Specimens placed in the frame for reaction to fire test

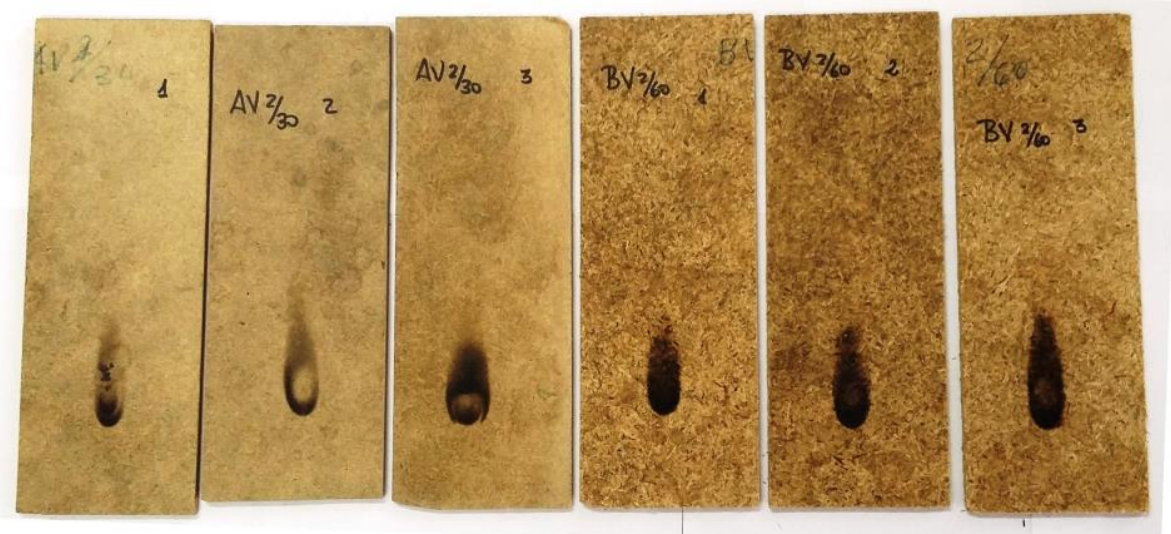

Fig. 3. Samples after the fire reaction test

The results are shown in Table 4 where $F_{\mathrm{s}}$ is the measured height of the burnt portion of the sample. As deduced from this figure, the burnt area was superficial. The results did not depend on the particle size. The EN ISO 11925-2 (2002) standard classifies the materials according to the parameters on Table 4. It states that when $F_{\mathrm{s}}<$ $150 \mathrm{~mm}$ in a time span of $60 \mathrm{~s}$, the boards are classified as flammability class B. If there has not been any flaming droplets, which was the case, the boards are classified as d0. Therefore, the binderless rice straw particleboards were classified as $\mathrm{Bd} 0$. The flammability tests were performed to determine if the boards could be classified as a superior class.

Table 4. Results of the Fire Reaction Test

\begin{tabular}{|c|c|c|c|c|c|c|c|}
\hline $\begin{array}{c}\text { Board } \\
\text { Particle } \\
\text { Size } \\
(\mathrm{mm})\end{array}$ & $\begin{array}{c}\text { Weight Loss } \\
(\%)\end{array}$ & $\begin{array}{c}\text { Burnt Height } \\
(\mathrm{mm})(\mathrm{Fs})\end{array}$ & $\begin{array}{c}\text { Burnt Width } \\
(\mathrm{mm})\end{array}$ & $\begin{array}{c}\text { Board } \\
\text { Ignition }\end{array}$ & Combustion & $\begin{array}{c}\text { Filter } \\
\text { Paper } \\
\text { Ignition }\end{array}$ & Smoke \\
\hline$<0.25$ & $0.19(0.029)$ & $51.43(6.53)$ & $17.77(2.68)$ & Yes & No & No & No \\
\hline $\begin{array}{c}0.25 \text { to } \\
1.00\end{array}$ & $0.17(0.020)$ & $52.24(4.88)$ & $18.09(0.63)$ & Yes & No & No & No \\
\hline
\end{tabular}

Values in parenthesis represent standard deviations- Fs: measured burnt height of the flame spread 
Wood particleboards are class Dd0, meaning that their reaction to fire is not as noticeable as that of rice straw particleboards. This could be explained by the high content of silica in the rice material, which is a known fire retardant (Lee et al. 2014).

There are seven fire classes according to the European Standard EN-13501-1: 2007+A1 (2009). Classification is a means to consider the building material contribution to the generation and spread of fire and smoke within the room of origin or in a given area. Products are generally considered in relation to their end use application. Class A is for products that will not contribute to the fire load and fire growth, like stone and concrete. Class $\mathrm{F}$ is for products with no reaction to fire performance determined, or for products that cannot be classified in one of the other classes. Class B is as Class C, but it satisfies more stringent requirements. In accordance to their end use, wood-based panels are Class D, but the results obtained classified the experimental panels as Class B, in the same category as gypsum boards, fire-retardant wood, and fire-retardant polymers.

In this study the reaction to the fire test used corresponds to a first phase in the development of a fire, where the fire affects a small area of a product. The second phase of the development of a fire corresponds to a fire growing in a room where a burning object is placed in a corner before it reaches a flashover. In a future study the rice straw panels of the present study can be further tested to find out their performance in such a situation. In this case the method to follow is described in the standard EN 13823 (2014).

\section{CONCLUSIONS}

1. Binderless boards were successfully manufactured from rice straw through hot pressing using a three-step process at a low temperature $\left(110{ }^{\circ} \mathrm{C}\right)$ and pressure $(2.6$ $\mathrm{MPa})$.

2. The physical-mechanical properties depended highly on the particle sizes used and on the pressing times.

3. Particleboard types 8 and 9 exceeded the minimum requirements for general uses (P1 grade, EN 312 (2010))

4. The boards could be considered as thermal insulating panels, due to the low results obtained. This property did not depend on the particle size nor the pressing time.

5. The reaction to the fire test showed that binderless rice straw particleboards can be classified as class B, in the same category as gypsum boards, fire-retardant wood, and fire-retardant polymers. To further test the rice straw particleboards in the development of a fire the method of the single burning item could be used.

\section{REFERENCES CITED}

Boquillon, N., Elbez, G., and Schonfeld, U. (2004). "Properties of wheat straw particle boards bonded with different types of resin," J. Wood Sci. 50(3), 230-235. DOI 10.1007/s10086-003-0551-9

Bouajila, J., Limare, A., Joly, C., and Dole, P. (2005). "Lignin plasticization to improve binderless fiberboard mechanical properties," Polym. Eng. Sci. 45(6), 809-816.

DOI: $10.1002 /$ pen.20342 
EN 310 (1993). "Wood-based panels. Determination of modulus of elasticity in bending and of bending strength," European Committee for Standardization, Brussels, Belgium.

EN 312 (2010). "Particleboards. Specifications," European Committee for Standardization, Brussels, Belgium.

EN 317 (1993). "Particleboards and fibreboards. Determination of swelling in thickness after immersion in water," European Committee for Standardization, Brussels, Belgium.

EN 319 (1993). "Particleboards and fibreboards. Determination of tensile strength perpendicular to the plane of the board," European Committee for Standardization, Brussels, Belgium.

EN 323 (1993). "Wood-based panels. Determination of density," European Committee for Standardization, Brussels, Belgium.

EN ISO 11925-2 (2010). "Reaction to fire tests - Ignitability of products subjected to direct impingement of flame - Part 2: Single-flame source test," European Committee for Standardization, Brussels, Belgium.

EN 12667 (2001). "Thermal performance of building materials and products.

Determination of thermal resistance by means of guarded hot plate and heat flow meter methods. Products of high and medium thermal resistance," European Committee for Standardization, Brussels, Belgium.

EN 13501-1:2007 + A1 (2009). "Fire classification of construction products and building elements - Part 1: Classification using data from reaction to fire tests," European Committee for Standardization, Brussels, Belgium.

EN 13823 (2014). "Reaction to fire tests for building products. Building products excluding floorings exposed to the thermal attack by a single burning item." European Committee for Standardization, Brussels, Belgium.

EN 13986:2004 + A1 (2015). "Wood-based panels for use in construction. Characteristics, evaluation of conformity and marking." European Committee for Standardization, Brussels, Belgium.

FAO Cereal supply and Demand brief (2015) Retrieved the $25^{\text {th }}$ of January 2016 from www.fao.org/worldfoodsituation/csdb/en/

Ferrandez-Garcia, C. E., Andreu-Rodriguez, J., Ferrandez-Garcia, M T., FerrandezVillena, M., and Garcia-Ortuño, T. (2012). "Panels made from giant reed bonded with non-modified starches," BioResources 7(4), 5904-5916. DOI:

10.15376/biores.7.4.5904-5916

Ghaffar, S.H. and Fan, M. (2014). "Lignin in straw and its applications as an adhesive," International Journal of Adhesion \& Adhesives 48, 92-102. DOI: 10.1016/j.ijadhadh.2013.09.001

Halvarsson, S., Edlund, H., and Norgren, M. (2010). "Manufacture of high-performance rice straw fibreboards," Ind. Eng. Chem. Res. 49(3), 1428-1435.

DOI: $10.1021 /$ ie901272q

Han, G. P., Umemura, K., Zhang, M., Honda, T., and Kawai, S. (2001). "Development of high-performance UF-bonded reed and wheat straw medium-density fiberboard," $J$. Wood Sci. 47(5), 350-355. DOI: 10.1007/BF00766784

Hervillard, T., Cao, Q., and Laborie, M.-P. G. (2007). "Improving water resistance of wheat straw based medium density fiberboards bonded with aminoplastic and phenolic resins," BioResources 2(2), 148-156. DOI: 10.15376/biores.2.2.148-156 
Kurokochi, Y., and Sato, M. (2015). "Properties of binderless board made from rice straw: The morphological effect of particles," Ind. Crop. Prod. 69, 55-59. DOI: 10.1016/j.indcrop.2015.01.044

Lee, C.H, Salit M.S., and Hassan, M.R. (2014). "A review of the flammability factors of kenaf and allied fibre reinforced polymer composites," Advances in Materials Science and Engineering Vol. 2014, Article ID 514036, 8 pp. DOI: 10.1155/2014/514036

Li, X. J., Cai, Z. Y., Winandy, J. E., and Basta, A. H. (2010). "Selected properties of particleboard panels manufactured from rice straws of different geometries," Bioresource Technol. 101(12), 4662-4666. DOI: 10.1016/j.biortech.2010.01.053

Lindström, T., and Westman, L. (1980). "The colloidal behaviour of kraft lignin. III. Swelling behaviour and mechanical properties of kraft lignin gels," Colloid. Polym. Sci. 258(4), 390-397.

MacLean, J.D. (1941). “Thermal conductivity of wood.” Heating, piping \& air conditioning. 13(6), 380-391.

Park, J., Seyama, T., Shiroma, R., Ike, M., Srichuwong, S., Nagata, K., Arai-Sanoh, Y., Kondo, M., and Tokuyasu, K. (2009). "Efficient recovery of glucose and fructose via enzymatic saccharification of rice straw with soft carbohydrates," Biosci. Biotech. Bioch. 73(5), 1072-1077. DOI: 10.1271/bbb.80840

Pintiaux, T., Viet, D., Vandenbossche, V., Rigal, L., and Rouilly, A. (2015). "Binderless materials obtained by thermo-compressive processing of lignocellulosic fibers: A comprehensive review," BioResources 10(1), 1915-1963. DOI: 10.15376/biores.10.1.1915-1963

Rials, T. G., and Wolcott, M. P. (1997). "Physical and mechanical properties of agrobased fibers," in: Paper and Composites from Agro-Based Resources, R. M. Rowell, R. A. Young, and J. K. Rowell (eds.), CRC Press, Boca Raton, FL, USA.

Sauter, S. L. (1996). "Developing composites from wheat straw," in: Proceedings of the 30th International Symposium of Washington State University on Particleboard/Composite Materials, Pullman, Washington, pp. 197-214.

Sjöström, E. (1993). Wood Chemistry. Fundamentals and Applications. Second Ed., San Diego, USA. Academic Press, Inc. (ed.).

Zhang, D., Zhang, A., and Xue, L. (2015). "A review of binderless fiberboards and its self-bonding mechanism,” Wood Sci. Technol. 49(4), 661-679. DOI: 10.1007/s00226015-0728-6

Article submitted: May 8, 2017; Peer review completed: September 3, 2017; Revised version received and accepted: September 22, 2017; Published: September 28, 2017. DOI: $10.15376 /$ biores.12.4.8539-8549 